\title{
Determination of Bacterial Quality of Water in Randomly Selected Swimming Pools in Kampala City, Uganda
}

\author{
Joyce Margaret Ekopai, ${ }^{1}$ Nathan Lubowa Musisi, ${ }^{2}$ Howard Onyuth, \\ Benigna Gabriela Namara, ${ }^{3}$ and Celsus Sente ${ }^{1}$ \\ ${ }^{1}$ Department of Wildife and Aquatic Animal Resources (WAAR), School of Veterinary Medicine and Animal Resources (SVAR), \\ College of Veterinary Medicine, Animal Resources and Biosecurity (COVAB), Makerere University, P.O. Box 7062, Kampala, Uganda \\ ${ }^{2}$ Department of Pharmacology and Therapeutics, School of Biosecurity, Biotechnical and Laboratory Sciences (SBLS), \\ College of Veterinary Medicine, Animal Resources and Biosecurity (COVAB), Makerere University, P.O. Box 7062, Kampala, Uganda \\ ${ }^{3}$ Medical Research Council (MRC)/Uganda Virus Research Institute (UVRI), Research Unit on AIDS, P.O. Box 49, Entebbe, Uganda
}

Correspondence should be addressed to Celsus Sente; csente37@gmail.com

Received 6 February 2017; Revised 30 April 2017; Accepted 18 May 2017; Published 14 June 2017

Academic Editor: Chrissanthy Papadopoulou

Copyright ( 2017 Joyce Margaret Ekopai et al. This is an open access article distributed under the Creative Commons Attribution License, which permits unrestricted use, distribution, and reproduction in any medium, provided the original work is properly cited.

\begin{abstract}
Swimming pools have become major recreation facilities for leisure and sports in cities across the world, but the standard guidelines, particularly in developing countries, are not adhered to because little is known about the contaminants in the pools and the possible health risks involved. This study provides a survey of bacterial quality of water from swimming pools in Kampala. A total of 26 water samples were collected from 13 outdoor swimming pools in Kampala between January and June 2016 and analysed for total aerobic plate count (TPC), Escherichia coli, coliforms, and Salmonella. The heterotrophic bacterial load ranged between 0 and $6.35 \times$ $10^{5} \mathrm{cfu} / \mathrm{ml}$, where $6.35 \times 10^{5} \mathrm{cfu} / \mathrm{ml}$ was the highest load and $3 \times 10^{1} \mathrm{cfu} / \mathrm{ml}$ the least. The highest average TPC was $6.19 \times 10^{5} \mathrm{cfu} / \mathrm{ml}$ and the lowest $5.07 \times 10^{3} \mathrm{cfu} / \mathrm{ml}$. $30.8 \%$ of the pools had TPC within acceptable limits $\left(\leq 5 \times 10^{2} \mathrm{cfu} / \mathrm{ml}\right)$, whereas $69.2 \%$ were highly contaminated and did not conform to the Uganda National Water and Sewerage Corporation standards of recreational water quality for both treated $(0 \mathrm{cfu} / 100 \mathrm{mls})$ water and untreated $(10 \mathrm{cfu} / 100 \mathrm{mls})$ water. Although no positive results were yielded for $E$. coli, coliforms, and Salmonella, TPC represented the presence of heterotrophic bacteria which are often indicated in opportunistic infections.
\end{abstract}

\section{Background}

Swimming pools are increasingly being used by man for swimming and other recreational based activities such as canoe polo, underwater rugby, volleyball, and sports diving. They are also used in certain cultural practices such as baptism, where the individual's head is submerged for a while as prayers are being conducted. Due to their increasing uses, swimming pools are now available at many recreation centres, hotels, motels, schools, beaches, universities, wildlife parks, homes, and many other areas. With such an increase in the numbers of swimming pools, high maintenance is necessary to protect the users from any form of infection.

Swimming pools are supplied by the water of environmental origin. The portability of swimming pool water is enhanced by frequently changing the water and the use of disinfectant, such as chlorine. The highest possible concentration of about 1 part per million ( $\mathrm{ppm}$ ) is advised to be maintained because higher chlorine concentration irritates the eyes $[1,2]$. Some swimming pool operators prefer iodine to chlorine as a disinfectant because its action is less hindered by organic matter and there is less eye and skin irritation compared to chlorine [1]. Although it is known that swimming pool water should meet potable water standards by being a clean, transparent, odourless, and tasteless liquid having a freezing point of $0^{\circ} \mathrm{C}$ and boiling point of $100^{\circ} \mathrm{C}$ [3], such standards are not normally maintained in many countries. In developing countries, particularly Uganda, there are no maintained standards or regulatory framework to ensure that swimming pools are not hubs for pathogen infection or other 
dangers. This coupled with a high rate of system breakdown, high maintenance costs, negligence, and ignorance poses a high risk to the swimming pools users.

The poor management of water supply systems to the pools and the use of unprotected water pose a high risk of pathogen transfer to humans. The microbial safety of swimming pool water is highly questionable in countries with poor regulatory framework due to the many existing possible microbial contaminant pathways. Microbial contamination of swimming pools can occur through (a) faecal contaminated source water or direct defecation from swimmers, birds, and animals [4-7], (b) nonfaecal human shedding from vomiting, sneezing, mucous, spitting, or skin, (c) poor wastewater disposal [8], (d) microbial biofilm formation along piped water networks $[9,10]$, (e) contaminated air, dust, soil, or rainwater [11, 12], and (f) individuals with contagious diseases or infectious pathogens $[4,8]$.

A number of common water contaminants grouped as viruses, bacteria, protozoa, and helminths have been studied worldwide. Unless the pool is cleaned and maintained and its water adequately treated, contamination may lead to a number of disease outbreaks such as gastroenteritis, conjunctivitis, keratitis, trachoma, otitis, cholera, dysentery, eczema, skin rashes, typhoid, dysentery, giardiasis, cryptosporidiosis, helminthiasis, cholera, hepatitis, rotavirus infection, salmonellosis, and central nervous systems associated diseases [3, 13-23]. The aetiologic agents of some of these diseases have been isolated from natural and domestic water sources in Uganda and are associated with devastating illnesses $[9,10,24,25]$. Not much has been studied about microbial contamination of swimming pool water in Uganda, but available data denotes the presence of Streptococcus and Escherichia coli $[26,27]$. Elsewhere in the world, a lot of research has been done, and pools have been associated with outbreaks of waterborne infections in humans [4, 28-31], often leading to severe morbidities and mortalities.

Although modern day swimming pools have a recirculating system for the water to be filtered, purified, and disinfected adequately, recent studies reveal that neither advanced technological systems nor disinfectants can obviate the colonisation of the pool water with some dangerous pathogens [32-34]. It has also been reported that the surviving disinfectant tolerant pathogens might also be antibioticresistant, a fact already documented for bacterial isolates from treated drinking water [4] and purified sewage effluents [35]. It is important to continuously test swimming pool water for the availability of pathogens that pose public health risks to humans in order to optimise water treatment methods to get the best performing chemicals that can kill or reduce these pathogens to minimal or nonworrying levels $[9,10,24]$. In Uganda, there is scanty information on the general hygiene of swimming pools. In 2007, Kampala City Council Health Division sounded a warning of the likely poor quality of swimming pool water in Kampala. Despite such concerns, there is no evidence indicating that the problem has been addressed. This is dangerous because research in many areas across the world has shown that swimming pools easily get contaminated by users and the surrounding environment. The objective of the present study was to investigate the bacterial quality of water in randomly selected swimming pools in Kampala City, Uganda.

\section{Methods}

2.1. Study Area. The study was carried out in Kampala city, the capital and largest city in Uganda, with an area of $189 \mathrm{~km}^{2}$. The city is divided into five Divisions that oversee local planning: Kampala Central Division, Kawempe Division, Makindye Division, Nakawa Division, and Lubaga Division. The city is located at $0^{\circ} 20^{\prime} 25.191^{\prime \prime} 32^{\circ} 38^{\prime} 8.9658^{\prime \prime}$ with $1223 \mathrm{~m}$ (4012 ft) elevation above sea level.

2.2. Site Selection and Sample Size. A cross-sectional study was carried out between January and June 2016. A purposive sampling strategy was employed, and only outdoor swimming pools in the city centre were selected for sampling. The study involved sampling of all the 13 outdoor swimming pools in the city centre.

2.3. Sample Collection, Storage, and Transportation. A total of twenty-six samples were collected in sterile well-labeled $500 \mathrm{ml}$ wide-mouthed bottles. Water samples were collected, when no bathers were in the pools (access was denied during the maximum bather density). To dechlorinate the water samples, sodium thiosulphate $(100 \mathrm{mg} / \mathrm{l})$ (Na2S2O3, sodium thiosulphate pentahydrate, 106509, Merck KGaA, Darmstadt, Germany) was added to each bottle. The samples were collected from a depth of $30 \mathrm{~cm}$ at a point about $50 \mathrm{~cm}$ away from the pool edge. The samples were transported at $4{ }^{\circ} \mathrm{C}$ within 1 hour from the collection time, using appropriately insulated coolers, to the microbiology laboratory at the College of Veterinary Medicine and Animal Resources and Biosecurity (COVAB), Makerere University. They were processed immediately after arrival at the laboratory.

\subsection{Laboratory Analysis}

2.4.1. Total Aerobic Plate Count. The total plate count (TPC) agar media was prepared according to the manufacturer's instructions [36] and poured into Petri dishes. It was then incubated at $37^{\circ} \mathrm{C}$ for 18 hours to determine the sterility. The samples were 10 -fold serially diluted in $9 \mathrm{ml}$ of sterilised peptone water contained in each of the tubes by transferring $1 \mathrm{ml}$ of water in the first test tube and mixed; then $1 \mathrm{ml}$ of the first dilution was drawn out into the second tube. This was continued until the 4th tube. Then $100 \mu \mathrm{l}$ of two sample dilutions of $10^{-2}$ and $10^{-4}$ including the neat (undiluted sample) was plated onto the plate count agar and the surface spread using a sterilised glass spreader for uniform inoculation. The plates were incubated at $37^{\circ} \mathrm{C}$ for 48 hours. Following appropriate length of incubation, all visible colonies were counted and the results were calculated by multiplying the number of colonies on each plate by the reciprocal of the dilution factor of sample dilution plated and multiplied by ten, which was reported as colony forming units per $\mathrm{ml}$.

2.4.2. Determination of Total Coliform and E. coli Count. Peptone water was prepared according to the manufacturer's 
TABLE 1: Water sample bacterial counts.

\begin{tabular}{|c|c|c|c|c|c|}
\hline Pool number & Sample number & Total plate count & Coliform & Escherichia coli & Salmonella \\
\hline \multirow{2}{*}{ F } & F1 & 102400 & 0 & 0 & 0 \\
\hline & $\mathrm{F} 1 \mathrm{H}$ & 301480 & 0 & 0 & 0 \\
\hline \multirow{2}{*}{$\mathrm{F} 2$} & F2 & 301320 & 0 & 0 & 0 \\
\hline & F2T & 635000 & 0 & 0 & 0 \\
\hline \multirow{2}{*}{$\mathrm{R}$} & $\mathrm{RN}$ & 300000 & 0 & 0 & 0 \\
\hline & RS & 300000 & 0 & 0 & 0 \\
\hline \multirow{2}{*}{$\mathrm{T}$} & TIH & 100000 & 0 & 0 & 0 \\
\hline & TIT & 100000 & 0 & 0 & 0 \\
\hline \multirow{2}{*}{ M } & MH & 30 & 0 & 0 & 0 \\
\hline & MT & 400000 & 0 & 0 & 0 \\
\hline \multirow{2}{*}{ K } & KlT & 300000 & 0 & 0 & 0 \\
\hline & $\mathrm{K} 1 \mathrm{H}$ & 40 & 0 & 0 & 0 \\
\hline \multirow{2}{*}{ K2 } & $\mathrm{K} 2 \mathrm{~T}$ & 0 & 0 & 0 & 0 \\
\hline & $\mathrm{K} 2 \mathrm{H}$ & 0 & 0 & 0 & 0 \\
\hline \multirow{2}{*}{ M2 } & M2H & 0 & 0 & 0 & 0 \\
\hline & M2T & 0 & 0 & 0 & 0 \\
\hline \multirow{2}{*}{ J } & $\mathrm{JIH}$ & 4000 & 0 & 0 & 0 \\
\hline & JIT & 2140 & 0 & 0 & 0 \\
\hline \multirow{2}{*}{$\mathrm{J} 2$} & $\mathrm{~J} 2 \mathrm{H}$ & 1020 & 0 & 0 & 0 \\
\hline & $\mathrm{J} 2 \mathrm{~T}$ & 100000 & 0 & 0 & 0 \\
\hline \multirow{2}{*}{ G } & GIH & 0 & 0 & 0 & 0 \\
\hline & GIT & 0 & 0 & 0 & 0 \\
\hline \multirow{2}{*}{ R2 } & $\mathrm{R} 3 \mathrm{H}$ & 400000 & 0 & 0 & 0 \\
\hline & R3T & 504000 & 0 & 0 & 0 \\
\hline \multirow{2}{*}{ G2 } & G2H & 0 & 0 & 0 & 0 \\
\hline & G2T & 0 & 0 & 0 & 0 \\
\hline
\end{tabular}

instructions [36-38] and $9 \mathrm{ml}$ was dispensed into test tubes and sterilised by autoclaving. Additionally, MacConkey agar media was prepared according to the manufacturer's instructions and sterilised by autoclaving [36]. The MacConkey agar was cooled, dispensed in Petri dishes, and incubated overnight to test for sterility. The sample was diluted and, with the aid of a sterile tip of $100 \mu \mathrm{l}$ of the sample, a homogenate from the serial dilution was transferred to the surface of the MacConkey agar and inoculated by surface spreading using sterile spreaders and then incubated at $37^{\circ} \mathrm{C}$ for 18 hours. All pink colonies were counted as coliforms and E. coli colonies were identified as pink, flat, dry surfaces, with small-tomedium-sized colonies. Biochemical tests were conducted to confirm the presence of $E$. coli using indole for the formation of a pink ring on sides of the tube at the top of inoculated peptone water [37, 38].

2.4.3. Isolation of Salmonella. Water samples were inoculated in buffered peptone water and incubated overnight at $37^{\circ} \mathrm{C}$ as the preenrichment stage. Then $1 \mathrm{ml}$ of the enriched sample was transferred to $9 \mathrm{ml}$ of selenite (Merck, Germany) broth and incubated at $42^{\circ} \mathrm{C}$ overnight. Thereafter, it was mixed carefully and cultured on prepared Xylose Lysine Deoxycholate (Oxoid, UK) by surface spreading using sterile spreaders and incubated for 24 hours at $37^{\circ} \mathrm{C}$. Salmonella colonies were identified as pink medium-sized colonies with black centres due to the production of hydrogen sulphide gas. Confirmation of Salmonella was done through the Triple Sugar Iron test for yellow butt and red slant with hydrogen sulphide gas production. It was also nonmotile, citrate, and urease-negative.

2.4.4. Data Management and Analysis. The results were recorded in a laboratory book and later entered into Microsoft Excel. The data was then double entered in Excel for quality control purposes. Tables were drawn for total plate counts (TPC), E. coli, coliform, and Salmonella counts. A bar graph of averaged TPC for each swimming pool was drawn to show the trends of the contamination.

\section{Results}

3.1. Total Aerobic Load of Pool Water. The results of the laboratory analysis are presented in Table 1 and Figure 1. Water sample F2T from pool F2 had the highest TPC with $6.35 \times$ $10^{5} \mathrm{cfu} / \mathrm{ml}$. Water sample MH from pool M had the lowest TPC count with $3 \times 10^{1} \mathrm{cfu} / \mathrm{ml}$. Similarly, pool F2 had the highest average TPC $\left(6.19 \times 10^{5} \mathrm{cfu} / \mathrm{ml}\right)$ and pool J the lowest $\left(5.07 \times 10^{3} \mathrm{cfu} / \mathrm{ml}\right)$ (Figure 1). Six water samples, K2T, K2H, $\mathrm{M} 2 \mathrm{H}, \mathrm{M} 2 \mathrm{~T}, \mathrm{G} 2 \mathrm{H}$, and G2T, from swimming pools K2, M2, 
TABLE 2: Summary of positive and negative samples and pools.

\begin{tabular}{lcc}
\hline Number & Positive & Negative \\
\hline Swimming pools $(n=13)$ & $9(69.2 \%)$ & $4(30.8 \%)$ \\
Samples $(n=26)$ & $18(69.2)$ & $8(3.8)$ \\
\hline
\end{tabular}

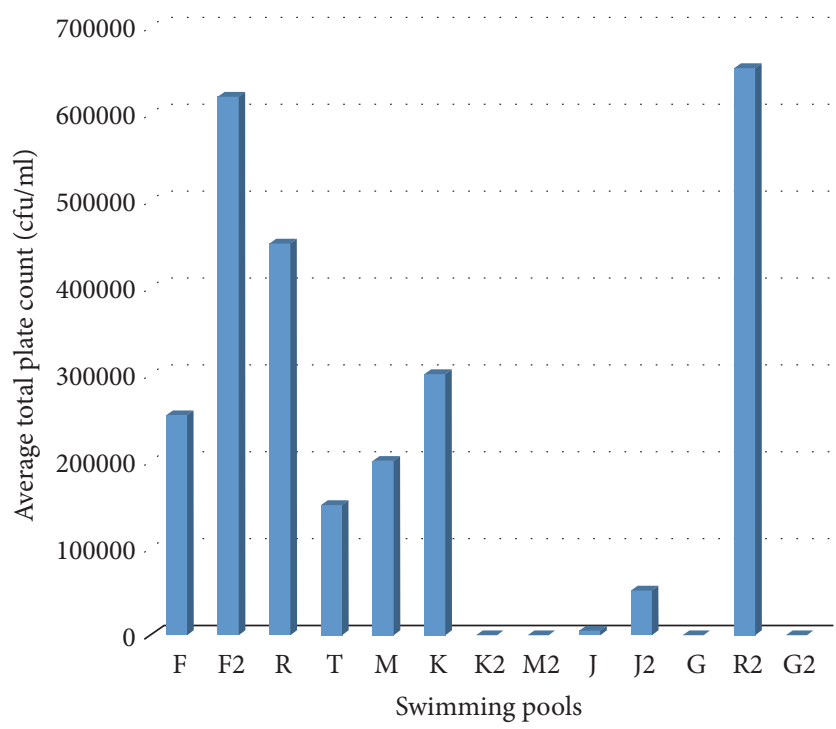

FIGURE 1: Average bacterial counts for 13 swimming pools.

G, and G2 exhibited no growth on the media; that is, four swimming pools (30.8\%) were free from microbial contamination, whereas $9(62.2 \%)$ had contamination (Table 2). Eighteen swimming pool samples (69.2\%) had TPC above acceptable limits of the Uganda National Water and Sewerage Cooperation standards of recreational water quality for both portable treated water $(0 \mathrm{cfu} / 100 \mathrm{mls})$ and untreated water $(10 \mathrm{cfu} / 100 \mathrm{mls})$. Eight samples $(30.8 \%)$ out of the twenty-six water samples analysed had TPC within the acceptable limit $\left(\leq 5 \times 10^{2} \mathrm{cfu} / \mathrm{ml}\right)($ Table 1$)$.

3.2. Total Coliform and E. coli Count of the Pool Water. After separate repeat runs of these tests using peptone water and MacConkey agar, there was a failure to demonstrate coliform and $E$. coli in the water samples analysed. Dilutions of water samples were analysed (i.e., $10^{-2}$ and $10^{-4}$ ) as well as the undiluted ones, but none of them had growth in the media.

3.3. Isolation of Salmonella. Following all the appropriate procedures and ample length of incubation periods using buffered peptone water for enrichment stage, selenite broth, and Xylose Lysine Deoxycholate agar for incubation, Salmonella growth did not occur.

\section{Discussion}

The total coliform and E. coli tests yielded no positive results, an indication that faecal contamination of these pools was unlikely, since $E$. coli, a quite potent indicator of faecal contamination, was not detected. The total aerobic plate count (TPC) which is a nonspecific test for everything including coliforms (if they are present) yielded positive results. TPC does not give an indication of the types of organisms present or their probable sources but indicates the culturable organisms present, which could be low or high total bacteria present [39].

In the present study, the results of the investigation according to TPC indicated an overall high microbial count in the swimming pool water. Seventeen (68\%) of the swimming pool samples collected had TPC above the acceptable limits of National Water and Sewerage Corporation (NWSC) and World Health Organisation $\left(>5 \times 10^{2} \mathrm{cfu} / \mathrm{ml}\right)$. There is no maximum acceptable concentration (MAC) specified for TPC microbes in water supplied by public or semipublic water systems but an increase in TPC concentrations above baseline levels $\left(>5 \times 10^{2} \mathrm{cfu} / \mathrm{ml}\right)$ is what is considered undesirable or unsafe [39]. A number of reasons could be attributed to this level of contamination. Kampala City swimming pool owners have little adherence to the national swimming pool or portable water standards because of poor enforcement of laws, ignorance, and negligence. This has resulted in all kinds of uncouth practices in the pool water. There is always very high bather density, and often the water appears dirty. This coupled with the probability of soil contamination from rainfall runoff and bacterial biofilm formation along the pipelines or other organic matters could be responsible for the contamination. Swimming pool contamination as a result of high bather density and organic matter contamination is common especially in poorly maintained pools [40, 41]. If swimming pools adhered to the National Water and Sewerage Cooperation guidelines, there would be minimal microbial contamination. Studies by previous researchers have shown that swimming pools in major hotels and cities in developed nations have low microbial contamination, ranging from 0 to $25 \%$ (38-43). However, the results from the swimming pools in Kampala indicate absolutely very high microbial contamination with heterotrophic bacteria. Our results concur with finding elsewhere in developing countries, where total plate counts exceeded the WHO limit $\left(>5 \times 10^{2} \mathrm{cfu} / \mathrm{ml}\right)[4,5,42]$.

The results of this study asserted that a high number of swimming pools in Kampala City did not conform to internationally and nationally acceptable standards, as is in most other developing countries. Lack of appropriate maintenance equipment and lack of well-trained human resources are the commonest reasons for increased contamination of swimming pools in Kampala. According to CDC [13, 43-45], lack of proper pool hygiene could lead to building up of pathogenic organisms.

The commonly isolated swimming pool organisms such as coliforms or E. coli and Salmonella species were absent in all the samples analysed in this survey, in spite of following all the procedures and giving ample length for incubation. This could be attributed to consistent chlorine and iodine use in disinfecting the pools, which may have low-to-moderate effectiveness in killing other microbes. According to CDC [43, 44] and Craun et al. [46], E. coli, coliforms, and Salmonella should be absent in 100-500 ml sample following appropriate 
disinfection of swimming pools. The disinfection may not eliminate certain highly resistant organisms, and often different disinfectants have to be used at varying doses. It is possible that the TPC represented the presence of water-dwelling organisms such as Acinetobacter, Aeromonas, Chryseobacterium (Flavobacterium), Klebsiella, Moraxella, Serratia, Pseudomonas, and Xanthomonas, Bacillus, Mycobacterium tuberculosis, Mycobacterium avium, Pseudomonas aeruginosa, and Legionella pneumophila that are emerging and reemerging pathogens capable of causing severe opportunistic infections, especially in immunocompromised individuals $[8,39,47]$.

In developed nations, swimming pools with efficient circulation systems have strainer baskets which continuously filter off solid materials to prevent contamination [48]. Unfortunately, most pools in Uganda do not have an efficient water circulation system. Water is changed when it is deemed as dirty by the pool attendants, and this is based on mere observation instead of having a standard testing system to rely on. The pool attendants believe that once a disinfectant is used, the pool is automatically safe. They do not look at this in terms of quantity of the disinfectants and the time lag. Much as a number of the swimming pool owners and users (bathers) are aware that contaminated pools are a source of serious infections, there has been minimal change in their use in ways that are likely to be safe. It is a big puzzle to explain this but probably these individuals still require more sensitisation about swimming pools and diseases cycles. Increased awareness and sensitisation in terms of risk factors leading to disease acquisition is a good pathway towards efficient control and preventive mechanisms.

\section{Conclusions}

The study established that most popular swimming pools (68\%) around Kampala City were contaminated. Nevertheless, $32 \%$ yielded growth within the acceptable limits. The targeted organisms, coliforms, E. coli, and Salmonella, were not present in the pools; however, this did not guarantee the safety of the pools, since there was a high total aerobic plate count that consisted of other microbes capable of causing infections in humans.

\section{Additional Points}

To be able to protect swimming pool users from the risk of acquiring a number of pathogens, it is high time the government of Uganda enforced the adoption of existing national standards for recreational waters. The government should be tasked to build more effective portable water management and sanitation policies. There should be a commitment from the government to supply clean potable water to the communities and this initiative must be of high priority. Community programs must be initiated to educate people on water safety measures, personal hygiene, and water treatment processes. Access to improved water sources should be corroborated with access to improved sanitation and hygiene (personal hygiene, regular cleaning of vessels, proper storage, and treatment).

\section{Conflicts of Interest}

The authors declare that they have no conflicts of interest.

\section{References}

[1] A. L. Smith, Principles of Microbiology, CV Mosby, London, 5th edition, 1977.

[2] V. Chongsuvivatwong and L. Mo-suwan, "Evaluation of village piped water: a case study in southern Thailand," The Southeast Asian Journal of Tropical Medicine And Public Health, vol. 24, no. 4, pp. 631-635, 1993.

[3] S. C. Cairncross, D. G. Curtis, R. L. Feahem, and G. H. Bradley, Evaluation for village water supply planning, Chichester: John Wiley and Sons, 2000.

[4] C. Papadopoulou, V. Economou, H. Sakkas et al., "Microbiological quality of indoor and outdoor swimming pools in Greece: investigation of the antibiotic resistance of the bacterial isolates," International Journal of Hygiene and Environmental Health, vol. 211, no. 3-4, pp. 385-397, 2008.

[5] G. Masoud, A. Abbass, A. Abaza, and W. Hazzah, "Bacteriological quality of some swimming pools in Alexandria with special reference to Staphylococcus aureus," Environmental Monitoring and Assessment, vol. 188, no. 7, article no. 412, 2016.

[6] T. Kumar, S. Onichandran, Y. A. L. Lim et al., "Comparative study on waterborne parasites between Malaysia and Thailand: a new insight," The American Journal of Tropical Medicine and Hygiene, vol. 90, no. 4, pp. 682-689, 2014.

[7] S. Onichandran, T. Kumar, C. C. Salibay et al., "Waterborne parasites: a current status from the Philippines," Parasites \& Vectors, vol. 7, no. 1, article 244, 2014.

[8] WHO, Guidelines for Safe Recreational Water Environment: Coastal And Fresh Waters, World Health Organization, Geneva, Switzerland, 2003.

[9] C. Sente, J. Erume, I. Naigaga et al., "Xenic cultivation and genotyping of pathogenic free-living amoeba from public water supply sources in Uganda," New Journal of Science, vol. 2016, Article ID 6358315, 9 pages, 2016.

[10] C. Sente, J. Erume, I. Naigaga et al., "Occurrence and genetic characterisation of Acanthamoeba spp. from environmental and domestic water sources in Queen Elizabeth Protected Area, Uganda," Parasites \& Vectors, vol. 9, article 127, 2016.

[11] R. Cruickshank, J. P. Duguid, B. P. Marmion, and R. H. A. Swain, Medical Microbiology: A Guide to Laboratory Diagnosis And Control of Infections, Churchhill Livingstone, Edinburgh, Scotland, 12th edition, 1975.

[12] M. M. A. El-Salam, "Assessment of water quality of some swimming pools: A case study in Alexandria, Egypt," Environmental Monitoring and Assessment, vol. 184, no. 12, pp. 7395-7406, 2012.

[13] CDC, "Domestic water, sanitation, and hygiene epidemiology USA: center for disease control, united states of America," http://www.cdc.gov/ncezid/dfwed/waterborne/domestic.html, 2015.

[14] CDC, "Neglected parasitic infections (NPIs) in the United States [internet], centers for disease control and prevention," http://www.cdc.gov/parasites/npi/, 2014.

[15] CDC, Parasites - Fascioliasis (Fasciola Infection), Center for Disease Control and Prevention, 2013. 
[16] G. Bwire, M. Malimbo, B. Maskery, Y. E. Kim, V. Mogasale, and A. Levin, "The Burden of Cholera in Uganda," PLoS Neglected Tropical Diseases, vol. 7, no. 12, Article ID e2545, 2013.

[17] G. Bwire, M. Mwesawina, Y. Baluku, S. S. E. Kanyanda, and C. G. Orach, "Cross-border cholera outbreaks in Sub-Saharan Africa, the mystery behind the silent illness: What needs to be done?" PLoS ONE, vol. 11, no. 6, Article ID e0156674, 2016.

[18] S. H. Choy, H. M. Al-Mekhlafi, M. A. Mahdy et al., "Prevalence and associated risk factors of Giardia infection among indigenous communities in rural Malaysia," Scientific Reports, vol. 4, article 6909, 2014.

[19] S. H. Choy, M. A. K. Mahdy, H. M. Al-Mekhlafi, V. L. Low, and J. Surin, "Population expansion and gene flow in Giardia duodenalis as revealed by triosephosphate isomerase gene," Parasites and Vectors, vol. 8, no. 1, article 1084, 2015.

[20] T. Gebru, M. Taha, and W. Kassahun, "Risk factors of diarrhoeal disease in under-five children among health extension model and non-model families in Sheko district rural community, Southwest Ethiopia: Comparative cross-sectional study," BMC Public Health, vol. 14, no. 1, article 395, 2014.

[21] G. S. Visvesvara, H. Moura, and F. L. Schuster, "Pathogenic and opportunistic free-living amoebae: Acanthamoeba spp., Balamuthia mandrillaris, Naegleria fowleri, and Sappinia diploidea," FEMS Immunology \& Medical Microbiology, vol. 50, no. 1, pp. 126, 2007.

[22] H. B. Nguendo Yongsi, "Pathogenic microorganisms associated with childhood diarrhea in low-and-middle income countries: case study of Yaoundé - Cameroon," International Journal of Environmental Research and Public Health, vol. 5, no. 4, pp. 213229, 2008.

[23] H. B. N. Yongsi, "Suffering for water, suffering from water: access to drinking-water and associated health risks in Cameroon," Journal of Health, Population and Nutrition, vol. 28, no. 5, pp. 424-435, 2010.

[24] C. Sente, J. Erume, I. Naigaga et al., "Prevalence of pathogenic free-living amoeba and other protozoa in natural and communal piped tap water from Queen Elizabeth protected area, Uganda," Infectious Diseases of Poverty, vol. 5, no. 1, article 68, 2016.

[25] S. Fuhrimann, M. S. Winkler, M. Stalder et al., "Disease burden due to gastrointestinal pathogens in a wastewater system in Kampala, Uganda," Microbial Risk Analysis, vol. 4, pp. 16-28, 2016.

[26] Monitor, "Ugandan Swimming Pools, a Pleasure With Risk," http://allafrica.com/stories/201202150043.html, 2012.

[27] D. Byamukama, F. Kansiime, R. L. Mach, and A. H. Farnleitner, "Determination of Escherichia coli contamination with chromocult coliform agar showed a high level of discrimination efficiency for differing fecal pollution levels in tropical waters of Kampala, Uganda," Applied and Environmental Microbiology, vol. 66, no. 2, pp. 864-868, 2000.

[28] K. D. Beer, J. W. Gargano, V. A. Roberts et al., "Outbreaks Associated with Environmental and undetermined Water Exposures - United States," Morbidity and Mortality Weekly Report, vol. 64, no. 31, pp. 849-851, 2015.

[29] M. B. Desilva, S. Schafer, M. K. Scott et al., "Communitywide cryptosporidiosis outbreak associated with a surface watersupplied municipal water system - Baker City, Oregon, 2013," Epidemiology and Infection, vol. 144, no. 2, pp. 274-284, 2016.
[30] M. C. Hlavsa, V. A. Roberts, A. M. Kahler et al., "Recreational water-associated disease outbreaks in United States," Morbidity and Mortality Weekly Report, vol. 63, no. 1, p. 10, 2009.

[31] J. E. Painter, J. W. Gargano, S. A. Collier, and J. S. Yoder, "Giardiasis surveillance-United States, 2011-2012," Morbidity and mortality weekly report. Surveillance summaries (Washington, D.C.: 2002), vol. 64, pp. 15-25, 2015.

[32] J. Barben, G. Hafen, and J. Schmid, "Pseudomonas aeruginosa in public swimming pools and bathroom water of patients with cystic fibrosis," Journal of Cystic Fibrosis, vol. 4, no. 4, pp. 227231, 2005.

[33] G. Dalmau, M. Estela Martínez-Escala, V. Gázquez et al., "Swimming pool contact dermatitis caused by 1-bromo-3chloro-5,5-dimethyl hydantoin," Journal of Contact Dermatitis, vol. 66, no. 6, Article ID 3350339, pp. 335-339, 2012.

[34] C. Hang, B. Zhang, T. Gong, and Q. Xian, "Occurrence and health risk assessment of halogenated disinfection byproducts in indoor swimming pool water," Science of the Total Environment, vol. 543, pp. 425-431, 2016.

[35] K. Kummerer, "Drugs, diagnostic agents and disinfectants in wastewater and water: a review," Schriftenr Ver Wasser Boden Lufthyg, vol. 2000, no. 105, pp. 59-71, 2000.

[36] APHA, "Microbiological examination, part 9000," in Standard Methods for the Examination of Water and Wastewater, L. S. Clesceri, A. Greenberg, and A. D. Eaton, Eds., vol. 12, pp. 308309, American Public Health Association, Washington, DC, USA, 20th edition, 1998.

[37] J. S. Cheesbrough, B. C. Taxman, S. D. R. Green, F. I. Mewa, and A. Numbi, "Clinical definition for invasive Salmonella infection in African children," Pediatric Infectious Disease Journal, vol. 16, no. 3, pp. 277-283, 1997.

[38] M. Cheesbrough, District Laboratory Practice in Tropical Countries, Cambridge University Press, Cambridge, UK, 2nd edition, 2006.

[39] WHO, Heterotrophic Plate Counts and Drinking-water Safety: The Significance of HPCs for Water Quality and Human Health, IWA Publishing, London, UK, 1st edition, 2003.

[40] A. Rabi, Y. Khader, A. Alkafajei, and A. A. Aqoulah, "Sanitary conditions of public swimming pools in Amman, Jordan," International Journal of Environmental Research and Public Health, vol. 5, no. 3, pp. 152-157, 2008.

[41] A. Rabi, Y. Khader, A. Alkafajei, and A. A. Aqoulah, "Sanitary conditions of public swimming pools in Amman, Jordan," International Journal of Environmental Research and Public Health, vol. 4, no. 4, pp. 301-306, 2007.

[42] G. Adjei G, S. K. Sarpong, E. Laryea, and E. Tagoe, "Bacteriological quality assessment of swimming pools in the osu-labadi area, Accra," Journal of Natural Sciences Research, vol. 19, pp. 126-129, 2014.

[43] CDC, Prevention of parasites in faecal material from chlorinated swimming pools, Centre for Disease Control, 2008, https:// www.cdc.gov/parasites/about.html.

[44] CDC, "Salmonella USA, Centers for Disease Control and Prevention," Centers for Disease Control and Prevention, https:// www.cdc.gov/salmonella/, 2016.

[45] CDC, Naegleria fowleri-Primary Amebic Meningoencephalitis (PAM)- Amebic Encephalitis: Pahogen and the environment, Centers for Disease Control and Prevention, 2016, https://www .cdc.gov/parasites/naegleria/state-map.html. 
[46] G. F. Craun, R. L. Calderon, and M. F. Craun, "Outbreaks associated with recreational water in the United States," International Journal of Environmental Health Research, vol. 15, no. 4, pp. 243262, 2005.

[47] WHO, Joint Monitoring Programme for Water Supply and Sanitation: Meeting the MDG Drinking Water And Sanitation Target; The Urban And Rural Challenge of The Decade, World Health Organization, Geneva, Switzerland, 2006.

[48] H. Tom, M. Dick, and F. Crane, How stuff works, Virginia, USA, 2015, http://home.howstuffworks.com/swimming-pool.htm. 

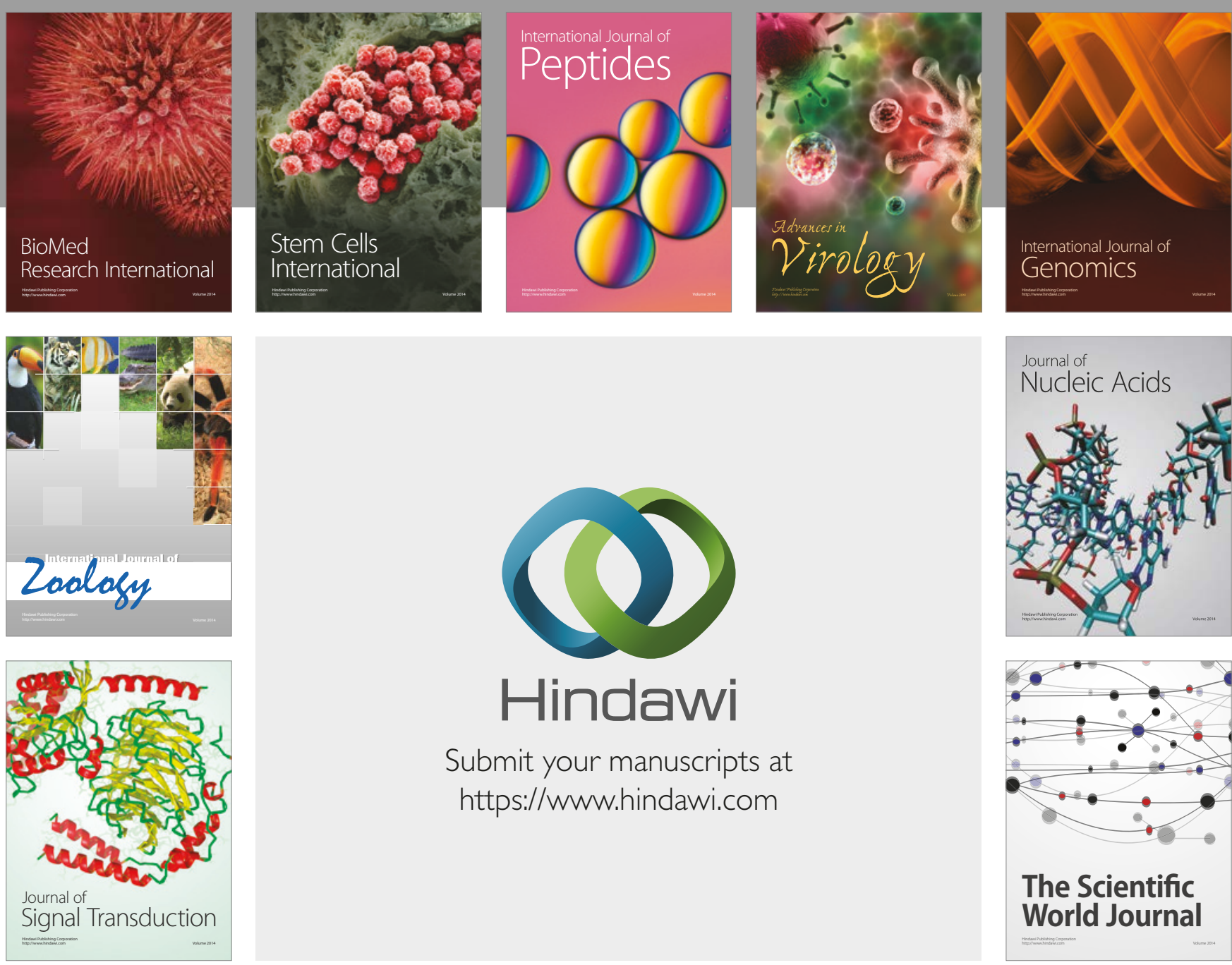

Submit your manuscripts at

https://www.hindawi.com
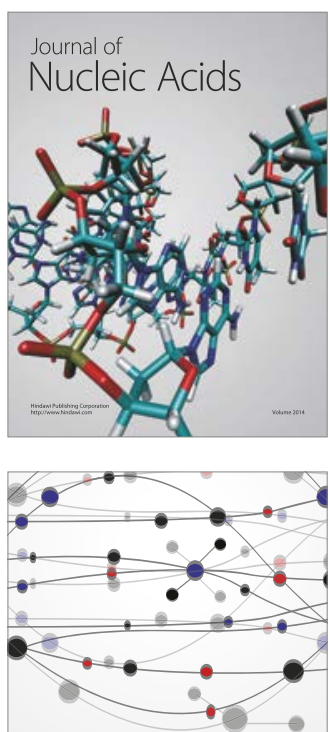

The Scientific World Journal

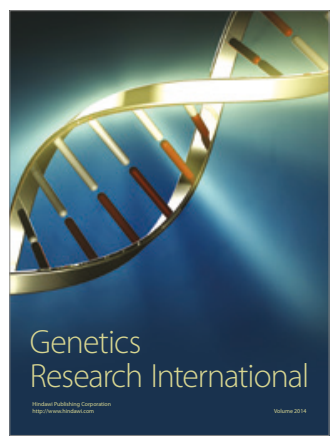

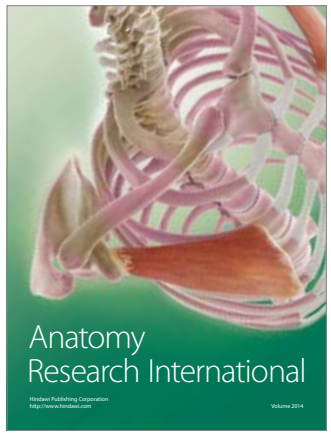

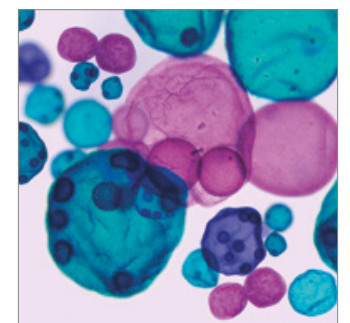

International Journal of Microbiology
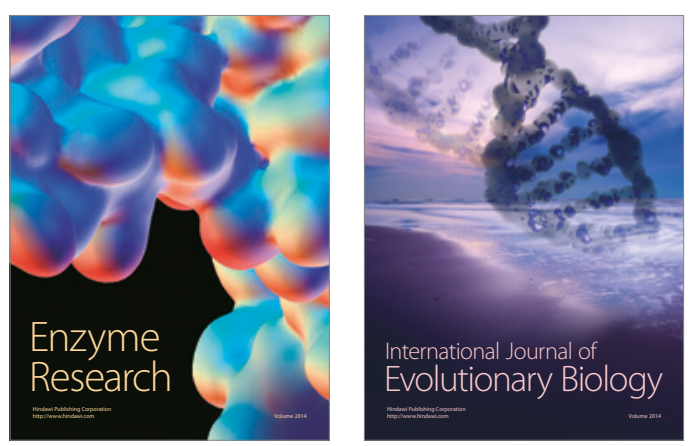
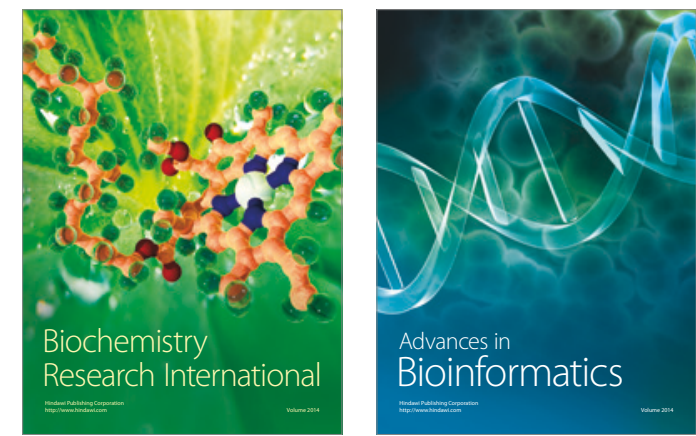

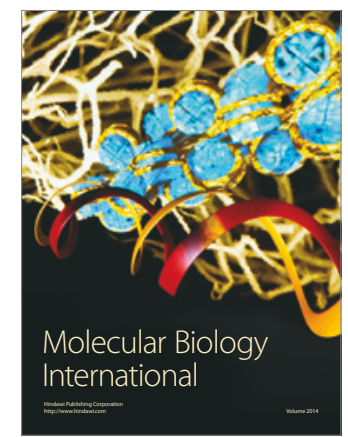

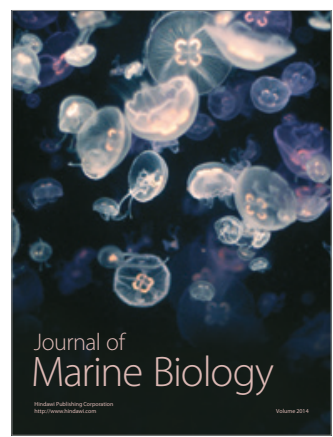

